\title{
FOSTERING CHARACTER THROUGH LITERATURE
}

\author{
Maria Bejjani \\ School of Education, American University in Dubai, Dubai, United Arab Emirates. email \\ maria.bejjani@mymail.aud.edu
}

\begin{abstract}
The shortage of moral character models today instigated teachers and policymakers to explore character education. Teachers play a substantial role in fostering and developing their students' characters. This study explores the perspectives of English Language Arts (ELA) teachers in the United Arab Emirates (UAE) on how to shape high school students' characters through literature. To gain insight into their viewpoints, interview-based qualitative research was conducted. The participants consisted of six UAE ELA teachers across genders and curricula. The results showed that, according to the teachers, literature can foster character when students make connections to relatable literature. The interviews also revealed that teachers believe in the need to guide and scaffold students' moral development and English fluency at varying levels. This study highlights the value of character education and means to develop it in the classroom.
\end{abstract}

Keywords: Character Education, Moral Education, Literature, English Language Learners

\section{INTRODUCTION}

The school's role in developing students' characters has been at the forefront of educational discourse in the region for the last decade. In 2016, the United Arab Emirates (UAE) announced the release of a mandatory Moral Education subject in school curricula across the country (Moral Education 2017b). By 2017, schools were teaching the subject from grades one through nine (Moral Education 2017b). Moral education programs focus on different understandings and interpretations of morality. Meanwhile, character education frameworks foster moral habits and behaviors. Nonetheless, both focus on moral development. As a student who got educated in the UAE, I began reflecting on the implications of not having undergone a formal moral or character education program myself.

I then realized that even within the previous curricula that did not include formal moral or character education many students still graduated with an understanding of what it means to embody good character. As an English Language Arts teacher, I also realized that many of the literary works discussed in the classroom have a moral component that students might carry with them. In fact, the Moral Education program in the UAE relies on stories, parables, and other readings to teach the various themes (Moral Education 2017a).

Many research studies demonstrate that the use of literature to foster character can be beneficial (Bennett 1993; FitzSimons 2013; Goldsmith 1940; Kilpatrick 1992; Kohn 1997; Leming 2000; Lickona 1991; Narvaez 2002). Nonetheless, there is limited research that addresses the teachers' perspective regarding classroom implementation. Through this research study, I highlighted teachers' viewpoints on whether the use of literature is relevant to character development.

I conducted this research to attempt to fill a gap in the existing literature by describing English Language Arts teachers' beliefs regarding shaping character through stories, especially in the context of the UAE. The findings lead to new perspectives about how character is fostered in young people and to an understanding of what teachers perceive as the value and goals of literature. Moreover, it provided insight on the relationship between character and literature. We live in a world where character is increasingly in short supply as contended by Lickona (1993). Any way that we can shed light on its importance to society and its 
place in the classroom matters more now than any other time in our lives.

The research study aimed to understand and describe the experience of various literature teachers in Dubai schools regarding fostering character within their literature classrooms. Thus, the research question guiding this study is: from the perspective of teachers, how, if at all, does the study of literature help to foster character in high school students in the UAE?

\section{LITERATURE REVIEW}

The conceptualization of character has evolved from Ancient Greece until the present. The literature reveals contention regarding the definition in the fields of philosophy, psychology, and education. Situationism, the idea that the determination of "good" character traits and values varies according to the circumstances (Miller 2017), manifests as a recurring source of dispute in the definition of character. As a result, psychologists have been reluctant to study and theorize about character because it is difficult to quantitatively research the concept (Goodwin, Piazza, and Rozin 2015). Lickona (1992) offers another outlook on character. As an educational researcher, he defines character as three interconnected processes between moral knowing, moral feeling, and moral action (Lickona 1992). Other educational researchers define character as the moral dimension and views of a person (Berkowitz, and Bier 2004; Francis 1962).

There are four generally recognized approaches to the teaching of character. First is the moral reasoning approach which is based on the studies of Piaget and Kohlberg on moral development. This approach has been adopted by many schools and educational systems. It focuses on teaching children to construct knowledge based on reason (Kilpatrick 1992). Nonetheless, this approach comes with an age restriction because, according to Piaget (1923) and Kohlberg (1977), children are unable to undergo moral reasoning on their own until they are nine or older.

Another approach is 'values clarification', which focuses on teaching students to interpret the world and construct their own value system (Arifin 2019; Bohlin 2015). The third approach stems from the socialemotional movement. It focuses on building skills such as conflict resolution, drug prevention, and other social skills that help in navigating society (Lapsley, and Narvaez 2006). The last approach concerns the direct instruction of values. The emphasis is predominantly on the rote cultivation of virtuous habits (Arifin, 2019; Edgington, 2002).

Researchers such as Bohlin (2005), Leming (2000), and Narvaez (2002) adopted approaches to intentionally teach character through literature. Narvaez (2002) and Leming (2000) highlighted the importance of students' reading method, moral development, and ability to discern and construct moral themes from literature. Bohlin (2005), on the other hand, outlined her own guidelines for interpreting moral themes from literature in classrooms. She suggested that, with the help of the teacher, students can engage in four processes: moral vision, moral rehearsal, moral identity, and moral judgment (Bohlin 2005, 30).

Carr (2014) discussed a prominent impediment to teaching character through literature. He maintained that many notable works of literature challenge the conventional societal virtues that schools want to deliver to their students. Alternatively, he suggested that it is these authentic literary texts that allow students to reflect deeply and to construct their own value beliefs (Carr 2014). Another limitation involves varying value perceptions. What people perceive is typically shaped by personal experiences and prior knowledge (Narvaez 2002). This becomes an issue because students in the same class may be at different stages of moral development. In this case, the concern for educators becomes the direction of a child's moral imagination (Kohn 1997).

The review of literature revealed varying perspectives on how literature shapes character. This study draws on the work done by the Bennett (1993), FitzSimons (2013), Goldsmith (1940), Kilpatrick (1992), Kohn (1997), Leming (2000), Lickona (1991), and Narvaez (2002) who established the benefits of using literature in building character. Accordingly, the study investigated UAE teachers' perspectives on shaping students' characters through literature.

\section{METHODOLOGY}

\section{Research Design}

To understand and interpret how literature teachers perceive the relationship between the literature they teach and the character of their students, I employed an interview-based qualitative approach. According to Merriam and Tisdell (2016), qualitative study aims to explore a human experience by observing and interpreting how people construct an understanding of their surroundings. Thus, a descriptive qualitative research design was most appropriate because it "seeks to discover and understand a phenomenon, 
process, or the perspectives and world views of the people involved" (Merriam 1998, 11). An interpretive qualitative approach allowed me to interact with educators to find diverse perspectives and discover patterns (Glesne 2016).

\section{Data Collection}

Participants of the study consisted of six English Language Arts teachers, four females and two males, from various UAE private schools, mostly following the American Curriculum. The participants teach at the secondary level with a minimum of two years in teaching experience within the UAE. I gained access to the participants through colleagues who provided me with the contacts. I approached the teachers and requested access to collect data through interviews. For confidentiality, they are referred to as participants $A$ to $\mathrm{F}$.

An encompassing definition of an interviewer's role is as "a collaborator whose conversational actions facilitate others in the telling of their stories" (Glesne 2016, 113). As the facilitator, I was also the data collection tool responsible for the comfort and ease of the interview. Accordingly, the semi-structured and open-ended interview questions were direct and simply worded. They were followed with probes to try to elicit more details from the participants.

Since the interviews were the primary source of data in this study, I conducted them with the utmost level of professionalism and comfort for the participants. Depending on the teachers' individual preferences, I held the interviews at the teachers' respective schools or in quiet coffee shops. My initial priority was building a rapport with the teachers to ensure their comfort and cooperation. I limited the length of the interview to a maximum of 40 minutes. At the beginning of the interview, I asked for the participant's consent to record the conversation to be able to stay focused in the moment and revisit the recording later.

During the data collection, I kept a field journal to keep track of my reflections, thoughts, and feelings in certain moments as well as descriptions of people, places, and situations. The field notes were dated. I also left space in my notes where I added more explanations, clarifications, and other expansions when rereading the notes at a later time. These included nonverbal communication, the participants' behavior, and the physical setting (Glesne 2016). The journal also included my transcriptions. All the documents were scanned and kept on my computer and an online drive for contingency.

\section{Data Analysis}

Data analysis is the process of interpreting the data. Since it is a process, that means that analysis is ongoing and iterative (Lichtman 2010). According to Merriam and Tisdell (2016), data analysis begins during data collection when a researcher makes decisions that narrow the topic down or even noting some analytical comments in the field journal. The data consisted of transcribed interviews and field notes. The notes were organized into categories within my field journal folder. Then, I continuously revisited and reread the notes and transcriptions to come up with themes. After multiple reads of the transcripts, I organized my data by color-coding themes across the interviews. Then, using descriptive coding, I assigned themes to the quotes. Afterwards, I used the comparative method to expose patterns, merge themes, and reduce irrelevant data.

\section{Ethical Considerations}

The ethical principles I embodied throughout this research are beneficence and non-maleficence. As a result, I ensured that I would do good through my research and avoid any harm towards the participants (Rumrill, Cook, and Wiley 2011). Primarily, this means guaranteeing the confidentiality of the participants. Before the initial interview, I assured them that their names and the school will remain anonymous and all documents related to my research process, including my notes and transcriptions, included only their pseudonyms. As for the recordings, they remained in my possession and on my personal devices. I also assured participants that they could choose to opt out of the research at any moment if they are uncomfortable.

\section{Research Bias}

As a literature teacher myself, I have my own perspective on the research topic. I believe that the central role of educating literature is to share the human experience. As a result, I consider that the main goal of Language Arts instruction is character development. Acknowledging my personal belief on the topic, I took the necessary precautions to preserve the legitimacy of the findings. First, by recognizing my biases, I avoided including my opinion on the topic. Moreover, I monitored my reactions and impressions on my field journal immediately after interviews to revisit and ensure that there was no judgment. I also saved my audit 
trail for further validation. Another way to ensure the trustworthiness of my research is through triangulation of data between the interview participants. I also employed peer debriefing systematically with educational research colleagues and my research advisor to minimize personal biases arising from investment in the subject.

\section{FINDINGS}

The analysis of the transcribed interviews and fieldnotes resulted in the emergence of the following four themes: literature changes lives, teacher's role, student's interest and readiness, and the impact of curriculum and context.

\section{Literature Changes Lives}

One of the recurring points that the participants stated was the relevance and purpose of literature in life. Participants indicated that the primary purpose of literature as a subject taught in school is communication and expression through language. Although voiced in various ways, all participants agreed that the purpose of literature extends beyond the classroom and the curriculum. For example, participant $E$ explained that the purpose of literature lies in discovering "the human condition," and "what it means to be human." Participant D drew upon the importance of literature in building positive teacher-student relationships by providing an outlet to share common life experiences. Participant $D$ also explained that the literature within the curriculum gave her students a voice; they utilized it as a tool to express themselves. Participant F described the role of literature as a place where "we learn ideals of life, we learn behavior. Sometimes it opens our minds to things that we will not be experiencing in real life." Participant B echoed the statement by explaining "There's nothing more emotionally healthy than being taken out of your own life and into someone else's."

All participants shared events in their professional or personal lives where the purpose of literature went beyond classroom intent. For example, Participant $C$ discussed how reading a book about a mountaineer who received an act of kindness while climbing Everest changed her life. She explained that a small act of kindness made the author raise funds to build schools all over Nepal in return. This piece of literature changed her world view on the importance of acts of kindness.

\section{Teacher's Role}

The participants' views on the role of the teacher in guiding the students' thinking varied greatly. Although all participants agreed that teacher involvement in the learning and analysis process is crucial, the extent of involvement differed. Participant B explained that mere exposure to literature with reflection can foster character. He believed that people naturally make connections to understand a text. This practice builds character. He also discussed that fostering character means considering all sides of a story. So, in his classroom, he often played devil's advocate to encourage students to think outside the box. For example, he shared the following:

There was a Jonathan Swift essay. He was talking about how you could sell your son or daughter. They [the students] were outraged by this. Well, then I said "Actually though, you know, if nowadays would you think of it. Is it unusual if a maid was 18 or 19 ? Well, back in those days maids were 12 . So maybe they were just finding a better life for their daughter by selling her to a rich family to be their maid." It wasn't necessarily what I thought about it, just trying to get them to look at it in a different way.

Participant $C$ reiterated the value of making connections; however, she also mentioned that students at a certain age who have limited life experiences might need some help. "I think that's where sometimes you have to... tell side stories and remember that your students ... are sometimes 14 . So, they haven't been in love yet. They haven't gone through a lot and had all these trials. So, you try to relate the stories to them, so that they do feel a connection to it."

On the other hand, Participant A believed that to foster character, a teacher must explain to students the skill of discerning the moral or theme from a literary work. She also discussed how she uses dramatization to guide students towards a better understanding of the characters' experiences, thoughts, and emotions. Dramatization is taking the role in a play of a character you are reading about. She said when referring to a certain student, "A part of her personality changed, and her parents told me that this helped her improve her self-confidence and self-esteem."

Participant $\mathrm{F}$ described the role of the teacher as one of guidance and provocation. She explained that the teacher's role in fostering character through literature is to frame the texts within lessons that interest the students and to ask questions to provoke deeper thinking. Additionally, she clarified that including an 
essential question could also motivate students to dig deeper and connect. "They give opinions. They argue based on behaviors." Participant D expanded by adding, "It would also, let's just say, uncover the journey that they're facing. The obstacles that they might face. So basically, those big questions, make them think because this is what we need in our life."

Participant E summarized his stance by saying, "I often say, my job as a teacher isn't to tell you what to think. It's to show you how." He discussed the importance of scaffolding as a strategy, in addition to the use of essential questions and probing. Most students at Participant E's school are English Language Learners (ELL). He further explained, with ELLs, to reach the depth that permits students to read between the lines, draw out universal themes, and connect to their lives, a teacher must scaffold the learning.

\section{Student's Interest and Readiness}

Another factor that affected fostering character is students' interest in the subject and their level of English fluency. Four out of the six participants identified that ELLs, who struggle to understand the texts, encounter the biggest obstacle in the classroom when discussing the morals of the story. The teachers discussed the impact of student readiness in terms of knowledge, skill, and affect.

Participant A proposed two main areas concerning students' role: interest and autonomy. First, she explained that "Some students might not be interested." She elaborated by saying that not all students realize the value or aim behind reading literature. Another point she emphasized was the importance of autonomy. She acknowledged the importance of students constructing their own moral knowledge because then "they tend to remember it more. It will be imprinted in their minds."

Participant B expected students to "see the bigger picture." He believed that character development through literature "happens fairly organically with the higher grades." Nonetheless, he emphasized that this growth varies greatly from one student to another depending on the students' readiness; he listed many factors that influence the growth of students. He discussed the importance of students' motivation, both intrinsic and extrinsic. Moreover, he also shared that "there's a few in each class that their English just isn't good enough to get what the writer means and therefore they can't." Additionally, he echoed Participant A's assertion regarding the importance of student interest.

Participant C's students were mainly composed of ELLs. Therefore, her students' readiness level is elementary. This demographic suggests that she has "some students in the classroom who cannot speak to me. I mean, barely get anything out. Then, I have others who can write well but as a second language." According to Participant $\mathrm{C}$, lack of proficiency in the English language seems to prevent students from interpreting and analyzing the text as a whole, and instead they are limited to line-by-line understanding. Participant $\mathrm{F}$ had a similar perspective. She explained, "Reading is the difficult part, not the inferencemaking." As a result, most character growth in their classrooms occurs through probing and writing activities.

Participants $D, E$, and $F$ recognized the importance of student readiness. Nonetheless, they held the view that the teacher has to scaffold the skills, to build background, and to engage the students. Participant $E$ added that the students' role in this circumstance is to develop an opinion. Through exposure to literature, students can also develop a taste for what they like. They use it to understand themselves better as people. One example from Participant E's classroom is "I've had girls thought they were not really into science fiction, but then they read Ray Bradbury. Then they think that's actually pretty cool."

\section{The Impact of Curriculum and Context}

In addition to the previous themes, the impact of the environment and the curriculum seemed to affect participants' perspectives on the potential of literature fostering character. The findings showed disagreement between participants on the importance of the content in the curriculum. Moreover, some participants faced cultural obstacles in discussing moral lessons.

Participant A noted that the having a choice in the content she teaches plays a major role. For example, she showed a great interest in reading and teaching mythology. She clarified how the various universal themes about mankind and human nature within myths make lessons more interesting and teaching more inclusive. Participant B echoed, "I'm limited to what the syllabus contains."

Participant B encountered some cultural issues associated with teaching in an Arab society. He cited an example where a student could not detach from values taught at home. The student could not consolidate what the author described with what her father taught her at home. Participant B explained that "I said, 'I think your father's right, but the writer doesn't really mean that.' She couldn't get past what she thought the writer meant. She would just say, 'No, my dad said that's wrong. I don't want to read that.' It was a mixture of 
a lack of understanding and just like something being triggered there as well."

Regarding content, Participant B did not believe that fostering character through literature is content-specific. However, he mentioned that he prefers teaching shorter poems because it allows for more discussion time. $\mathrm{He}$ also pointed out the value of incorporating modern literature into the curriculum. "I think they would be so interested in some of the stuff written in the last hundred years even, but we don't get to that... it's a pity we spent so much time in the past," expressed Participant B.

On the other hand, Participant $\mathrm{F}$ believed that the relevance of literature transcends time because of the universal themes they tackle. She believed that the content is not dated, it is the method of teaching. She elaborated that the teacher's role is to give the literature "life". Participant F emphasized, "The teacher is responsible for ... updating. The school is not to be blamed. The students cannot be blamed as well because the world is changing, and teachers have to acknowledge that."

Participant $C$ had a special case. As an educator in a UAE military school, her students were all Muslim and Emirati. Many moral dilemmas that she tackled in class included the ethics of war. As a result, she encountered some obstacles in this closely monitored system:

In my school, the one thing I have to really be careful of is whose morals I'm teaching, because they are Emirati, and all of them are Muslim... I made sure that any moral lesson that I'm teaching them is from their point of view because the military is very strict. One of the reasons why they limit our interactions with the students is they do not want foreign influence on their students. So, anything that I try to teach them, even morally, I relate it back to Islam.

Another obstacle Participant $C$ faced was the literary content at the military school. The sole focus is teaching the language and what students need to know to pass language tests, such as IELTS and TOEFL. As a result, the texts that the students receive are informational texts that leave little room for character development. She added, "I think literature can build character, as long as you're not teaching them about a vacuum cleaner." She said with frustration that, "It's disappointing that when you have the chance to teach these young students who are impressionable, who are thirsty for a lot of different information, to waste their time with literature that won't change their lives because our life is very short."

Another barrier associated with the schools that Participant $C$ observed was stress. She explained that students in high schools are under a lot of pressure because of the number of subjects that they need to take, the standardized tests, and the expectations from parents and teachers. They are only concerned with dissecting the text, reading Cliff Notes, and then moving on to the other tasks on their to-do list. They simply do not have the time to stop and appreciate literature.

Both Participant $C$ and Participant $E$ also defined the importance of contextual content that students can more easily relate to. Participant C observed, "Most of the stories are about any other person in the world except Arab." Participant E provided an example from assigning a Naguib Mahfouz novel into his grade 11 students. He explained, "It's a really compelling story, but the fact that it was set in an Arab culture... the kids were actually able to identify more. Despite the fact that they're not Egyptian, obviously, but still, there was that sense of familiarity."

\section{Discussion and Conclusion}

In discussing the findings of this study, I employ the definition of character in its broadest sense as suggested by Berkowitz, and Bier (2004) and Francis (1962). They described character as the moral dimensions and personality traits a person embodies. Accordingly, this section discusses teachers' perception regarding the role of literature in building and strengthening the moral dimensions and personality traits of high school students in the UAE. Based on the participants' perception and experience, I found that the study of literature fosters character through teacher guidance and scaffolding, the ability to empathize and make connections, and by circumventing certain limitations. In some ways, the findings agreed with the literature on the topic. However, the UAE context provides an additional set of challenges because the students are ELLs. Even so, there are some areas of contention and potential for further research.

\section{Guidance and Scaffolding}

All the participants believed that the teacher's role is imperative in fostering character. Given that students were non-native, English Language Learners (ELLs), students always needed some sort of scaffolding to unpack the text so that they can reach the deeper level of understanding suitable for growth.

In relation to the literature, secondary school students (ages 12 and above) should theoretically be at the 
autonomous stage of Piaget's theory of moral development. At this stage, they understand the relativity of morals, and they can construct their own perception of right or wrong, depending on the situation (Piaget 1932). Although Kohlberg did not assign age to the stages, the secondary students would typically be at stage five or six of his theory of moral development. In the fifth stage, they typically realize that the world was not black and white, and in the sixth stage, they establish their own moral understanding (Kohlberg, and Hersh 1977).

Based on what the participants described, the students struggled with understanding the text, but not with forming an opinion or a stance. Regardless, teachers mentioned instances where students needed probing to consider more sides of the story. For example, Participant B explained that he must play devil's advocate to provoke deeper thought into the literature. Also, five out of the six participants mentioned the use of essential questions to guide the students' thinking. This evidence shows that the students are also at varying levels of moral development which was problematic for some teachers in the classroom.

The literature highlighted the importance of the teaching approach when it comes to fostering character: the moral reasoning approach (Kilpatrick 1992), the values clarification approach (Arifin 2019; Bohlin 2015), the social-emotional approach society (Lapsley, and Narvaez 2006), and the values instruction approach (Arifin 2019; Edgington 2002). However, most of the participants described using a variety of approaches in the classroom depending on the students' needs. For example, Participant A used the values instruction approach when she told the students how and where to draw out universal themes from a text. However, when she applied dramatization in the classroom, she took a values construction approach.

\section{Making Connections}

All participants emphasized the importance of making connections to the literature in order to foster character. In fact, Participant $\mathrm{C}$ believed that students cannot even understand a text if they are unable to relate to it. Participants also explained how students empathized with characters by trying to put themselves in the characters' shoes.

The data coincides with the Bohlin's (2005) guidelines for interpreting moral themes from literature. Two of the processes she included are moral rehearsal and moral identity. To practice moral rehearsal, students must connect. To practice moral identity, students must empathize. It also coincides with Narvaez's (2002) and Leming's (2000) emphasis on active reading, which compels readers to connect with their lives and prior knowledge.

\section{Challenges}

Most challenges revealed by the participants did not correspond with those discussed in the literature. The obstacles Kohn (1997) highlighted, such as the goals of the program and the level of addressing the problem, were on a macro basis and the participants did not face these issues in the classroom. Other limitations that surfaced in the literature were curricular alignment (Bohlin 2005), censorship (Carr 2004), and varying value perceptions (Bohlin 2005).

None of the participants had a curricular alignment issue because they all believed that literature lessons were the natural habitat of moral discussions and character education. Moreover, the participants did not mention whether censorship was an issue. As a literature teacher in the UAE, I encountered censorship issues in topics related to religion, politics, and sexuality. Educators must refrain from discussing or exposing students to these issues to remain compliant with the rules set by the government.

Nonetheless, the participants hoped for some freedom of choice in the subject content. Participant B wanted more modern content in the course to show the contrast between classical literature and modern literature. Participant $\mathrm{C}$ and Participant $\mathrm{E}$ both wished to include Middle Eastern literature to provide more contextual material. They strived to believe in the literary work they teach and maximize the connection between students and reading.

Another challenge concerned varying value perceptions. Participants $B$ and $C$ both pointed to incidents with students who were unable to connect with authors because of their family values. Regardless, this obstacle arose because their students were at different stages of moral development and were unable to separate what they considered moral from what social norms indicate.

\section{RECOMMENDATIONS}

Through this research, I aimed to discover teachers' perspectives on how literature can foster character in the classroom. Teachers identified that high school students in the UAE need guidance and encouragement 
to empathize and make connections to the literature as they are mostly ELLs, and they are also at varying stages of moral development. So, reading contextual material that students relate to can facilitate the process of fostering character through literature. Attention to and possibly a reconceptualization of the content and methods utilized by UAE teachers and other educators regarding character education through literature is recommended, mainly to take into account the predominantly ELL student body.

\section{ACKNOWLEDGEMENT}

I was blessed with the greatest support system during writing this paper. My sincerest thanks go to my supervisor Dr. Nadera Alborno, who always pushed me to reach for the stars. I would also like to acknowledge Dr. Catherine Hill who always broadened my horizons and encouraged me to take risks. Finally, I would like to thank my students for setting a great example of what it means to be a passionate learner.

\section{REFERENCE LIST}

Arifin, Muhammad A. 2019. "Developmental History of Character Education and How It Could Be Defined." Ekspose: Jurnal Penelitian Hukum Dan Pendidikan 16 (2): 411-419. https://doi.org/10.30863/ekspose.v16i2.101

Bennett, William J. 1993. The Book of Virtues, New York: Simon \& Schuster.

Berkowitz, Marvin W., and Melinda C. Bier. 2004. "Research-Based Character Education." The Annals of the American Academy of Political and Social Science 591 (2004): 72-85. http://www.jstor.org/stable/4127636.

Bohlin, Karen E. 2005. Teaching Character Education through Literature: Awakening the Moral Imagination in Secondary Education. London: RoutledgeFalmer.

Carr, David. "Four Perspectives on the Value of Literature for Moral and Character Education." The Journal of Aesthetic Education 48 (4): 1-16. doi:10.5406/jaesteduc.48.4.0001.

Edgington, William D. 2002. "To Promote Character Education, Use Literature for Children and Adolescents." The Social Studies 93 (3): 113-116. doi:10.1080/00377990209599893.

Francis, E. Frank. 1962. "Fundamentals of Character Education.” The School Review 70 (3): 345-357. doi:10.1086/442632.

Glesne, Corrine. 2016. Becoming Qualitative Researchers: An Introduction (5th ed.). Boston: Pearson.

Goldsmith, Sadie. 1940. "The Place of Literature in Character Education.” The Elementary English Review 17 (5): 176-178. http://www.jstor.org/stable/41383282.

Goodwin, Geoffrey. P., Jared Piazza, and Paul Rozin. 2015. "Understanding the Importance and Perceived Structure of Moral Character." In Character: New Directions from Philosophy, Psychology, and Theology, edited by Christian B. Miller, R. Michael Furr, Angela Knobel, and William Fleeson, 100126. New York: Oxford University Press. doi: 10.1093/acprof:oso/9780190204600.003.0005.

Kilpatrick, William. 1992. Why Johnny Can't Tell Right from Wrong. New York: Simon \& Schuster.

Kohlberg, Lawrence, and Richard H. Hersh. 1977. "Moral Development: A Review of the Theory." Theory Into Practice 16 (2), 53-59. doi:10.1080/00405847709542675.

Kohn, Alfie. 1997. "How not to teach values: A critical look at character education." Phi Delta Kappan 78 (6): 429-439.

Lapsley, Daniel K., and Darcia Narvaez. 2006. "Character Education." In Handbook of Child Psychology, 248-296. New York, NY: Wiley. https://doi.org/10.1002/9780470147658.chpsy0407

Leming, James S. 2000. "Tell Me A Story: An Evaluation of A Literature-Based Character Education Programme". Journal Of Moral Education 29 (4): 413-427. doi:10.1080/713679388.

Lickona, Thomas. 1992. Educating for Character: how our schools can teach respect and responsibility. New York: Bantam.

Lickona, Thomas. 1993. “The Return of Character Education.” Educational Leadership 51 (3), 6-11. 
Lichtman, Marilyn. 2010. Qualitative Research in Education: A User's Guide (2nd ed.). Los Angeles: SAGE Publications.

Merriam, Sharan B. 1998. Qualitative Research and Case Study Applications in Education. Jossey-Bass Publishers, San Francisco.

Merriam, Sharan B., and Elizabeth J. Tisdell. 2016. Qualitative Research: A Guide to Design and Implementation (4th ed.). San Francisco, CA: Jossey-Bass.

Miller, Christian B. 2017. "Character and Situationism: New Directions." Ethical Theory and Moral Practice 20 (3), 459-471. https://doi.org/10.1007/s10677-017-9791-4

Moral Education. 2017a. "Curriculum." Accessed November 29, 2019, from https://moraleducation.ae/curriculum/

Moral Education. 2017b. "The Journey." Accessed November 29, 2019, from https://moraleducation.ae/thejourney/

Narvaez, Darcia. 2002. "Does Reading Moral Stories Build Character?" Educational Psychology Review 14 (2), 155-171. doi: 10.1023/A:1014674621501

Piaget, Jean. 1932. The Moral Judgment of the Child. London: Routledge \& Kegan Paul.

Rumrill, Phillip, Bryan G. Cook, and Andrew L. Wiley. 2011. Research in Special Education: Designs, Methods. Springfield, III.: Charles C. Thomas.

Ryan, Kevin. 1989. "In Defense of Character Education." Moral Development and Character Education, edited by Larry P. Nucci, 3-17. Berkeley, CA: McCutchan Publishing Corporation.

\section{ABOUT THE AUTHOR}

Maria Bejjani: Graduate Student, School of Education, American University in Dubai, Dubai, United Arab Emirates. 